\title{
Separation of a novel species from Actinopyga mauritiana (Holothuroidea: Holothuriidae) species complex, based on ecological, morphological and mitochondrial DNA evidence.
}

\section{Mohammed I. Ahmed}

Marine Science Department, faculty of science, Suez Canal University, Egypt.

\section{ABSTRACT}

Sea cucumbers are a diverse group of echinoderms, approximately more than 1,400 species around the world belonging to six orders and 25 families. In Egypt, sea cucumber is overfished along the Egyptian coast of the Red Sea and in most cases, species are being commercialized without a clear taxonomic identification. Two color morphs of the holothurian Actinopyga mauritiana were found in the Egyptian Red Sea coast and Gulf of Aqaba. Both morphs were found to have different habitats and depth preferences, morphological and molecular examination of both morphs along the Egyptian coast of the Red Sea uncovered new species diversity within the Actinopyga species complex and the discovery of novel species Actinopyga sp. nov.

Keywords: Sea cucumber; Actinopyga mauritiana; Red Sea; DNA barcoding; COI

\section{INTRODUCTION}

Actinopyga (Bronn, 1860) is one of the five genera in the family Holothuriidae (Rowe 1969; Rowe \& Gates 1995; Massinet al., 2004; Kerr et al 2005; Samyn et al., 2005). Within the genus there are sixteen species generally recognized as valid :Actinopyga agassizii (Selenka, 1867); A. albonigra (Cherbonnier and Féral, 1984); A. bacilla (Cherbonnier, 1980); A. bannwarthi (Panning, 1944); A. caroliniana (Tan Tiu, 1981); A. crassa (Panning, 1944); A. echinites (Jaeger, 1833); A. flammea (Cherbonnier, 1979); A. fusca (Cherbonnier, 1980); A. lecanora(Jaeger, 1833); A. miliaris (Quoy \& Gaimard, 1833); A. obese (Selenka, 1867); A. palauensis (Panning, 1944); A. serratidens (Pearson, 1903); A. spinea (Cherbonnier, 1980) and A. mauritiana (Quoy \& Gaimard, 1833). In his revision of the taxon, Panning (1944) recognized five species belonging to three main groups. Panning (1944) briefly mentioned the difficulty he had in placing A. mauritianaand, consequently, did not assign it to any of his groups. Rather, he opted for the safest solution and kept it as a separate species in the genus. He remarked that some ossicles of the ventral body wall (grains) resemble those found in the genus Bohadschia Jaeger, 1833.

Actinopyga mauritiana is a widespread species in the Indo-Pacific and the Red Sea (Yamanouchi, 1939; Bakus, 1968; Zoutendyk, 1989; Conand, 1998; Hopper et al., 1998). These holothurians graze on epifaunal algal films that consist mainly of plant debris and on brown and blue-green algae (Conand, 1990; Ramofafia et al., 1997). Worldwide, Actinopyga mauritiana is valued as a commercial species for which there is a high demand and is subsequently harvested in large numbers (Conand, 1990). In Egypt it is generally considered to be of high value given that more important commercial species have been overfished (Ahmed, 2006).

The species is characterized by a very thick and muscular body, cylindrical in shape, elongate, arched dorsally and flattened ventrally.

The dorsal surface is sometimes wrinkled, wider in the middle and tapered towards both ends. The anus is armed with five distinct white calcified anal teeth. The 
colour is very variable. The dorsal side may be greenish to chocolate brown with numerous light brown conical papillae whilst the ventral body wall is usually light grey to white. The mouth is ventral, surrounded by 25 dark brown, stout, peltate tentacles (Conand, 1990; Ramofafia et al,. 1997).

In Egypt the species inhabits a wide range of depths and habitats from the reef flat to $30 \mathrm{~m}$ deep. However, the majority of individuals were found between $5-10 \mathrm{~m}$ deep on coral reef, seagrass beds and sandy habitat (Ahmed, 2006). Furthermore, recent work has shown that animals collected from different parts of their range are able to differentially express a range of chemicals that have activity against candida, leishmanial promastigotes and cancer cell lines (Ahmed, 2006).

To overcome confusion in taxonomy, particularly in relation to species complex issues and cryptic species, there has been an increasing move to use molecular genetic techniques. Of these, one approach that is proving popular is DNA barcoding. This involves DNA sequence analysis of a uniform target gene to enable species identification (Hebert et al., 2003). Its advantage is that it uses mitochontrial DNA, a stable and very characteristic feature in the animals. A short DNA sequence should contain enough information to distinguish between different species. The cytochrome $c$ oxidase subunit I ( $\mathrm{COl}$ ) gene has been used in most barcoding studies because of its robust primers (Folmer et al.,1994). Results to date indicate that this CO1 barcode is easy to recover in diverse taxa, using a limited set of primers; readily aligned for sequence comparisons and effective in distinguishing among closely related species (Cox and Hebert, 2001).

The main aim of this work was to investigate the A. mauritiana species complex in more detail in order to investigate if it is formed of a single species of wide range of habitat/depth preferences or more than one species. We will use morphological; spicules; ecological and molecular examination in order to answer these questions. The molecular analysis will include the mitochondrial COI.

\section{MATERIALS AND METHODS}

\section{Samples collection and spicules variation}

Based on colour differences, five different morphotypes of $A$. mauritiana were available for analysis from the collection of the British Museum of Natural History (BMNH) (Ahmed, 2006). In addition, two of these morphotypes were collected from different sites along the Red Sea coast and Gulf of Aqaba in Egypt. Samples were collected using SCUBA. They were then relaxed and preserved in the field for morphological and genetic examination.

Ten individuals matching the description of the first morph of A. mauritiana were collected from coral reef habitat along the Red Sea coast of Egypt and Gulf of Aqaba. A further fifteen individuals matching the description of the second morph of A. mauritiana were collected from open seagrass beds around Hurgada.

In order to identify each individual species using morphological characters the following steps were considered. Dorsal and ventral surface colors were immediately recorded after collection. Anal teeth were counted and recorded immediately after collection. Tentacle type and numbers were recorded after relaxation of the specimens. After dissection of the specimens calcareous rings were examined and their type and length were recorded, other internal organs; respiratory trees and gonads were also counted and recorded. Samples from both dorsal, ventral surfaces and tentacles were taken for spicules preparation (Ahmed, 2006). 
Spicules preparation for identification purposes has to be made from different parts of the body of the specimen. These are: podia, dorsal papillae, dorsal tegument, ventral tegument and tentacles (Ahmed, 2006). For fast preparation of spicules a sample was taken from the desired tissues. This does not have to be very large, $(2 \mathrm{~mm}$ $\mathrm{X} 2 \mathrm{~mm}$ ideal). The sample was placed in the centre of a slide, on a flat surface free from dust and drafts. A large drop of neat bleach was then added over the sample with a pipette. This was left for 5-15 minutes for the tissue to dissolve, (may be more depending on the thickness of the tissue and strength of the bleach). The slide was then washed carefully with distilled water to remove the bleach and examined under a light microscope.

DNA was extracted from tentacle tissue sample per specimen using Qiagen DNA easy Tissue Kit \#69504 (Qiagen, Inc., London, UK) following the manufacturer's protocol. A region of the mitochondrial cytochrome oxidase I (COI) gene was amplified using primers described in (Table 1) (Ahmed, 2015). Polymerase chain reaction was performed which comprised a $94^{\circ} \mathrm{C} / 4 \mathrm{~min}$ initial denaturing step followed by 30 cycles of $94^{\circ} \mathrm{C} / 1 \mathrm{~min}, 55^{\circ} \mathrm{C} / 1 \mathrm{~min}$, and $72^{\circ} \mathrm{C} / 1 \mathrm{~min}$. A final elongation step of $72^{\circ} \mathrm{C} / 10 \mathrm{~min}$ was used. Products were then visualized on a $1.5 \%$ agarose gel stained with ethidium bromide. Remaining PCR products were used for sequence analysis.

Table 1: Oligonucleotide primers

\begin{tabular}{|c|c|}
\hline Primer & Sequence 5 '------------------3' \\
\hline COIe-F & ATA ATG ATA GGA GG (AG) TTT GG \\
\hline COIe-R & GCT CGT GT (AG) TCT AC(AG) TCC AT \\
\hline
\end{tabular}

Multiple COI sequences were manually entered and aligned using the codoncode aligner editor program. Sequence assembly and verification was performed with the aid of Aligner VX (Codon Codeinc, New York). The sequences were aligned using the clustal automated alignment algorithm then checked manually using Mesquite software where codon positions were assigned. These codon positions were used to create a codons partition file to specify the evolutionary model. The evolutionary model most appropriate for mtDNA sequence analysis is the General Time Reversible (GTR) model (Stamatakiset al., 2008) and this is the model used by all the leading maximum likelihood (ML) tree-building programs. ML trees were constructed using RAXML (Stamatakis et al., 2008) specifying the codon partitions described above as the only modification to the default parameters. Confidence in nodes was assessed using the bootstrap with 1000 pseudoreplicates performed in RAXML. Trees were uploaded into IToL (Letunic and Bork, 2006) and nodes with less than $50 \%$ support collapsed to reflect uncertainty in that aspect of the topology.

\section{RESULTS}

Differences were found in both habitat and depth preferences between the two morphs of A.mauritiana recorded in the Red Sea. While the first morph was found predominantly on shallow coral reef habitat the second morph inhabited sandy lagoons and seagrass habitats. They were also found in deeper water than the first morph. Habitat and depth preferences for both morphs are shown in (Figs. 1 and 2).

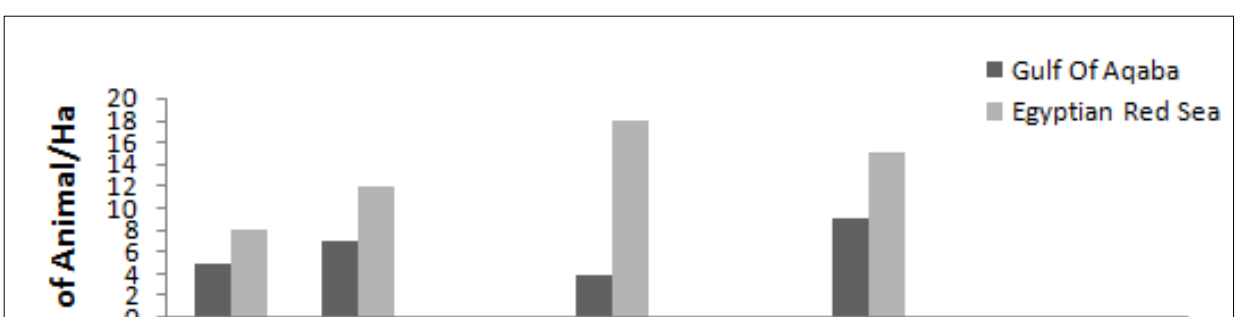


Fig. 1: Habitatpreferences of the two morphs of A.mauritiana along the Red Sea coast of Egypt and Gulf of Aqaba. Data represented as number of animals per hectare.

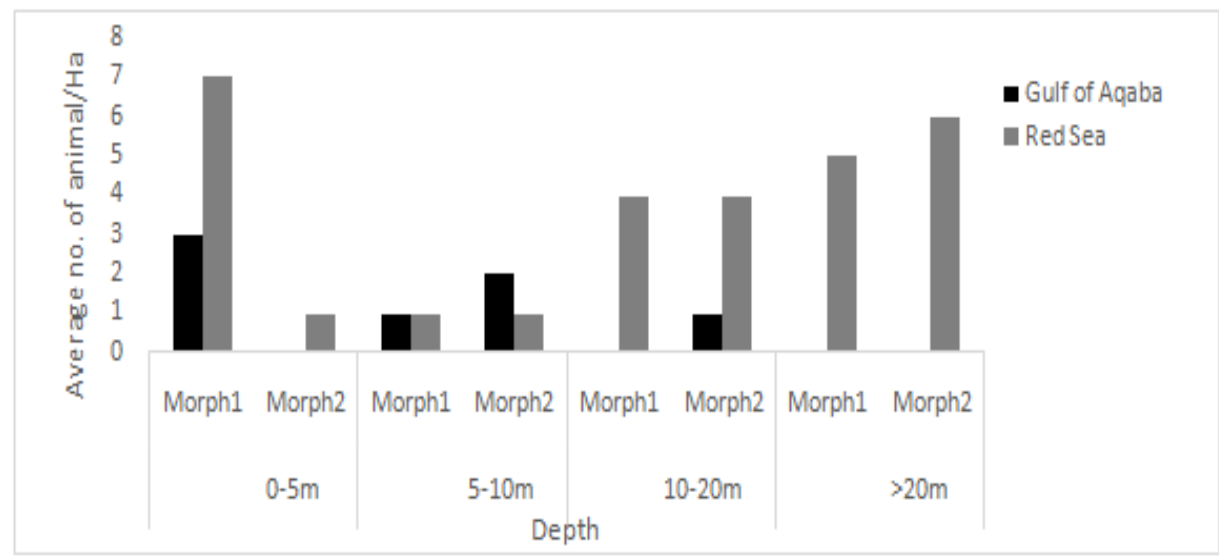

Fig. 2: Depth preferences of the two morphs of A. mauritiana along the Red Sea coast of Egypt and Gulf of Aqaba. Data represented as number of animals per hectare.

The two morphs of A. mauritiana along the coast of Egypt presented two different color patterns. The dorsal surface of the first morph was greenish to chocolate brown with numerous light brown conical papillae. The ventral body wall was usually light grey to white, sometimes pink in colour. The second morph was dark brown dorsally and white to pink ventrally (Fig. 3).

Both morphs of A. mauritiana had the same types of spicules. However, the body wall spicules of the second morph were characterized by the presence of more complex rosettes of various forms, some elongated with endings swollen, others wider and more spiny than the first morph. In addition, the ventral body wall of the second morph was composed of small grains, elongated grains and spiny or smooth rods that were mostly smooth in the case of the first morph (Fig. 4).
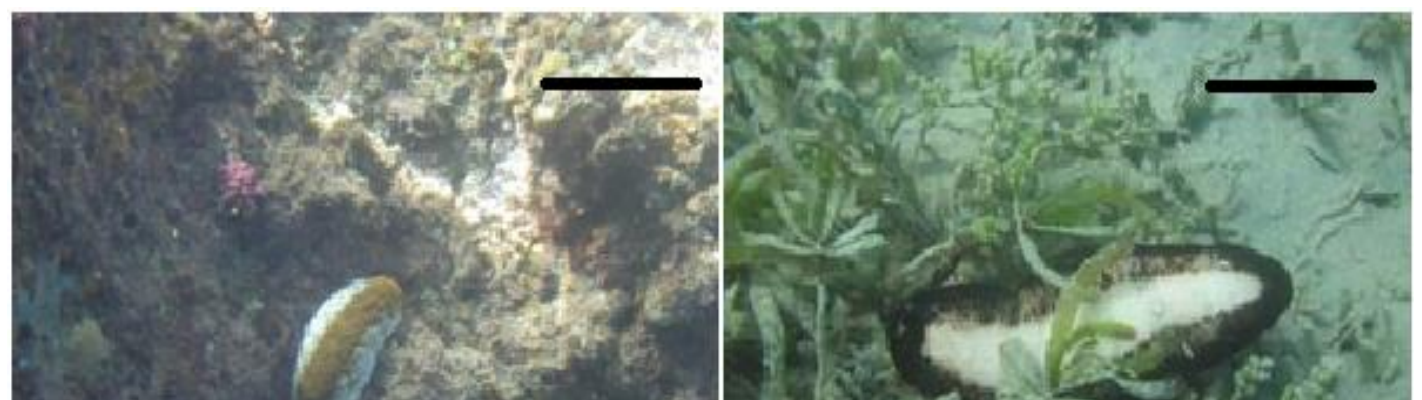
Fig. 3: Morphological characters of the two collected morphs of A. mauritiana

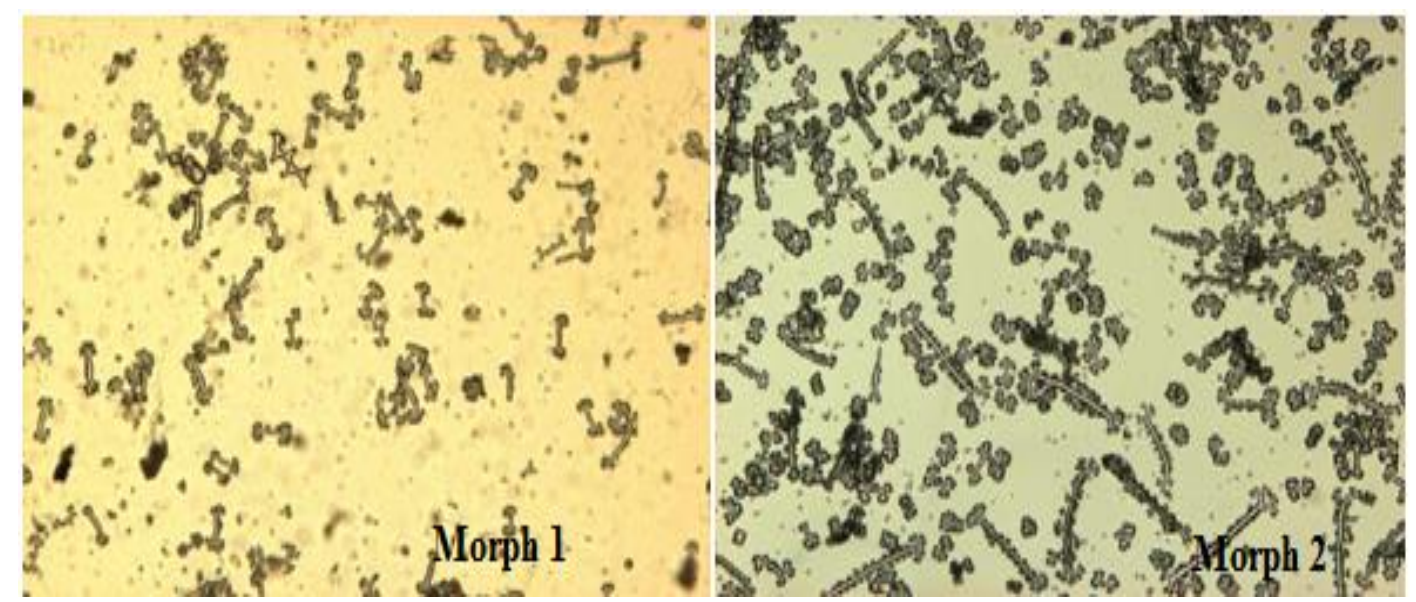

Fig. 4: Spicule differences of two morphs of A. mauritiana

Regarding the molecular study, DNA was extracted from 26 different individuals of A.mauritiana collected from different locations and habitat along the Red Sea coast and Gulf of Aqaba. PCR products were obtained and then sequenced for the COI mitochondrial gene.

The sequencing results for the COI gene of Actinopygamauritiana is shown in Fig. 5. This shows a tree for the COI for Actinopyga species of the Red Sea, the towA.mauritiana morphs from this study and Actinopygamiliaris and A.obesa obtained from the genebank.

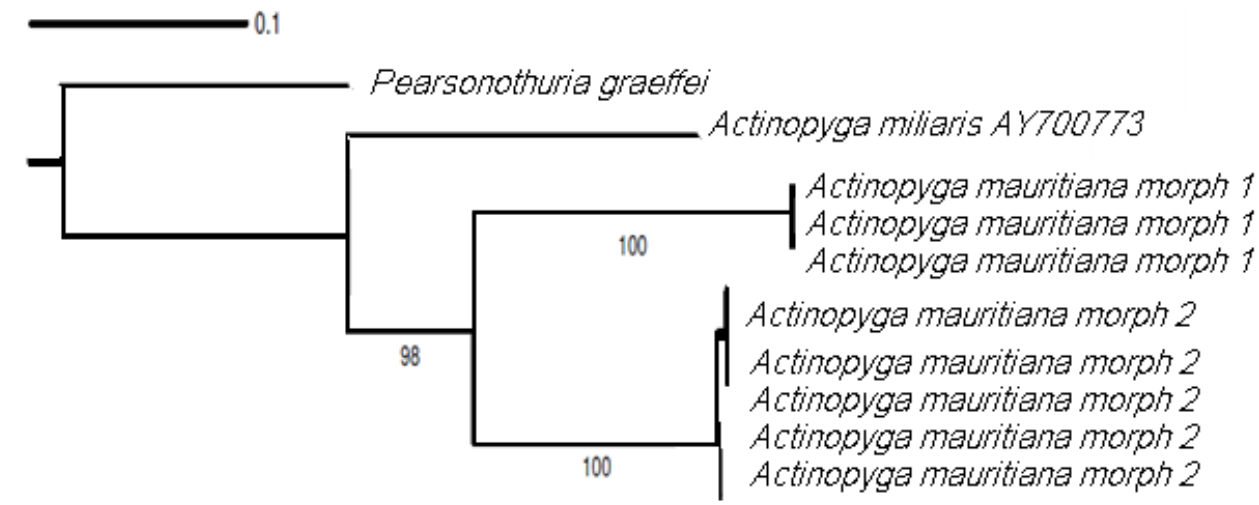

Fig. 5: Maximum likelihood tree for nine specimens from Actinopyga mauritiana morph1 and two of morph2 collected from the Egyptian Red Sea coast, and A. miliaris (AY700773) from Australia. Pearsonothuria graeffei from the Red Sea was used as outgroup.

\section{DISCUSSION}


The traditional use of morphological characters for species identification has several limitations; for example, the misidentification of taxa because of unclear morphological characters or being unable to identify the cutting point in similarity/differences between closely related species; the existence of cryptic taxa where the species will be reproductively isolated and morphologically similar (Knowlton, 1993). The DNA barcoding approach might currently represent the best solution for identifying species when their morphology is of limited use (Ahrens et al., 2007). The technique overcomes all of the previously mentioned limitation (Hebert et al., 2003).Even when morphological identification of a species is possible, DNA barcoding can be faster and cheaper (Gaston, and O'Neill, 2004). DNA barcoding also will overcome the problem of identifying animals when only small traces of tissues are available or the animal has been processed as food materials. It could also allow biodiversity assessment through the identification of taxa from the traces of DNA present in environmental samples such as soil or water.

In this study two different morphs of A. mauritiana were found. The ecological survey showed that they differ from each other in both their habitat and depth preferences. While A. mauritiana morph 1 prefered shallow exposed coral sites, the second morph was usually found in deeper water $>7 \mathrm{~m}$ on seagrass beds and sandy lagoons. This supports previous reports on A. mauritiana habitat and depth preferences. For example, while Samyan (2003) described A. mauritiana from seagrass beds and coral lagoons. Massin, (1996) described the species as a coral reef only species leading to the common name (surf red sea cucumber). Similarly, there has been continued debate in literature regarding depth preferences. While some described the animal as a shallow water species (0-7m) (Massin, 1996; Samyn, 2003), others recorded the species from deeper water.

There were also significant morphological differences between the two morphs collected from the Red Sea. The first morph the dorsal body surface is usually greenish to red colour and the ventral body surface is usually grey, while on the second morph the dorsal body surface is dark brown and the ventral body surface white-light pink. The spicule examination of the two morphs showed that they both have rods and rosettes matching the spicules description of $A$. mauritiana in literature (Massin, 1996; Samyn, 2003). However, the spicules of the second morph were more complex and elongated. Spicules of Actinopyga species are very similar in form and hence appear fairly ineffective in resolving relationships within the A. mauritiana species-complex. However, when considered in greater detail, they can, to some extent, be used to separate species.

The maximum likelihood analysis of the mitochondrial COI gene of the two morphs showed deep divergence between the two morphs. The genetic distance between A. mauritiana morph one and two equal the genetic distance between other well recognized holothurians species. Therefore, from this result it is clear that they are reproductively isolated and because of the deep divergence between them it is not a recent divergence but it is a very old stable one between the two morphs with genetic distance that is equal to the distance between well recognized Holothurian species.

Combined together, all morphological, ecological and molecular differences between the two morphs of $A$. mauritiana confirm with no doubt that the two morphs are reproductively isolated from each other and should not be considered as two morphs of the same species but rather two different species. The application of molecular biology is a much needed approach in the study of the systematic of seacucumber in general. Morphological characters including colour and spicule 
examination have generally been more a source of confusion rather than tools for answering taxonomic questions.

The other main challenge we faced in this study was to give one of the two morphs a new name, as both morphs satisfy the original description in literature for $A$. mauritiana. Morph two matches the description of the type sepecimens in the Museum of Natural History, while morph one matches the common name (surf red). Therefore, we agreed to rename morph one to Actinopygasp.nov. The common name for Actinopyga mauritiana will have to be revised as A. mauritiana inhabits seagrass and sandy lagoons and prefer such habitat on coral habitats. Further research is needed using DNA techniques in order to resolve taxonomic and identification problems of the Actinopyga morphs.

Our study matches the same pattern that was found on Holothurianobilis in the Great Barrier Reef in Australia (Uthicke, and Benzie, 2003), where the large genetic difference between $H$. nobilis in La Réunion and all other populations is greater than that between other echinoderm species (e.g. Lessios et al,. 2001), and suggests that $H$. nobilis individuals in La Réunion may be a different species. This is consistent with the different colour patterns observed in the West Indian Ocean region, but this colour pattern was included in the original description of $H$. nobilis (Uthicke, and Benzie, 2003). That might indicates the presence of hundred of hidden undiscovered species within the seacucumber as a group.

These results have broader conservation and ecological implications. The fact that the Red Sea as a habitat might have many more hidden unidentified species, it means that the total biodiversity of the Red Sea is much underestimated. All the conservation projects on Seacucumber management and sustainable use should also take in consideration the fact that there are unidentified species and genetic diversity that needs further research to be discovered, when planning protected areas and closed fishing season. We recommend that color and spicules still be recorded and described for specimens from this species-complex, for we have shown here that, when considered in greater detail than what is usually required in sea cucumber taxonomy, they can indicate monophyletic groups. However, the use of DNA barcoding techniques proves to be faster, easier and more accurate in identifying the new species and resolving some of the long standing taxonomic questions.

\section{AKNOWLEDGMENT}

This research was supported and funded by the STDF (Science and technology Development Fund). As part of project 5608 in Aquaculture of seacucumber and Giant clam.

\section{REFERENCES}

Ahmed, M. I. (2006). Taxonomic and fishery stock status of sea cucumber in the Egyptian Red Sea. MPhil Thesis, University of Hull.

Ahmed, M.I (2015). Use of DNA Barcoding Technique to Identify Museum and Cooked Sea Cucumber (Holothurians) Specimens. Catrina (2015), 12 (1): 101 -106@ 2015 by The Egyptian Society for environmental Sciences.

Ahrens, D., Monaghan, M. T.andVogler, A. P. (2007). DNA-based taxonomy for associating adults and larvae in multi-species assemblages of chafers (Coleoptera: Scarabaeidae). Molecular Phylogenetics and Evolution 44 (2007) 436-449

Bakus, G.J. (1968). Defensive mechanisms and ecology of some tropical holothurians. Mar. Biol., 2:23-32. 
Bronn HG. (1860). Die Klassen und Ordnungen der Strahlenthiere (Actinozoa) wissenschaftlichdargestellt in Wort und Bild. Klassen und Ordnungen des Theirreiches, Leipzig 1(2):1-434, 48 pls. [reference not seen; from Ludwig 1889-92].

Cherbonnier G. (1980). Holothuries de Nouvelle-Calédonie. Bulletin du Muséum national d'Histoirenaturelle de Paris, Quatrièmesérie 2, section A (3): 615-667.

Cherbonnier, G. and Féral, J.P. (1984). Les Holothuries de Nouvelle-Calédonie. Deuxième contribution (Première partie: SynallactidaeetHolothuriidae). Bulletin du Muséum national d'Histoirenaturelle, Paris Quatrièmesérie, 6, section A (3): 659700.

Conand, C. (1990). The fishery resources of Pacific island countries. Part 2: Holothurians. FAO Fish. Tech. Pap. 272.2, 143 p.

Conand, C. (1998). Holothurians. In: Carpenter, K. \&Niels, V. (eds.) FAO species identification guide. The marine living resources of the Western Central Pacific.vol. 2 cephalopods, crustaceans, holothurians and sharks, 1157-1190.

Cox, A. J. and Hebert, P. D. N. (2001). Colonization, extinction and phylogeographic patterning in a freshwater crustacean. Mol. Ecol., 10: 371-386.

Folmer, O., Black, M., Hoeh, W., Lutz, R., Vrijenhoek, R. (1994). DNA primers for amplification of mitochondrial cytochrome $\mathrm{c}$ oxidase subunit I from diverse metazoan invertebrates.Mol. Mar. Biol. Biotechnol., 3: 294-299.

Gaston, K. J. and O’Neill, M. A. 2004. Automated species identification: why not? Phil. Trans. R. Soc. Lond. B 359.

Hebert PDN, Cywinska A, Ball SL, deWaard JR. (2003). Biological identifications through DNA barcodes. Proc R Soc Lond B, 270: 313-321

Hopper, D.R., Hunter, C.L. and Richmond, R.H. (1998). Sexual reproduction of the tropical sea cucumber Actinopygamauritiana(Echinodermata: Holothuroidea), in Guam. Bulletin of Marine Science, 63:1-9.

Jaeger GF. (1833). De Holothuriis. Turici: 1-40, 3 pls..

Kerr AM, Janies D, Clouse RM, Samyn Y, Wheeler WC, Kim J. (2005). Molecular Phylogeny of Coral-Reef Sea Cucumbers (Holothuriidae: Aspidochirotida) based on 16S mtrDNA sequence. Molecular Phylogenetics and Evolution.

Knowlton, N. 1993.Sibling species in the sea.Annu. Rev. Ecol. Syst., 24:189-216.

Lessios, H.A., Kessing, B.D., Pearse, J.S. (2001). Population structure and speciation in tropical seas: global phylogeography of the sea urchin Diadema. Evolution, 55: 955-975.

Letunic and Bork. (2006). Bioinformatics23(1):127-8

Massin, C. (1996). Results of the RumphiusBiohistorical Expedition to Ambon (1990). Part 4. The Holothuroidea (Echinodermata) collected at Ambon during the RumphiusBiohistorical Expedition. ZoologischeVerhandelingen307, 1-53.

Massin, C., Samyn, Y., and Thandar, A.S. (2004). The genus Labidodemas (Echinodermata: Aspidochirotida: Holothuriidae) revisisted with description of three new species and with re-positioning of Holothuria (Irenothuria) maccullochi (Deichmann, 1958). Journal of NaturalHistory, 38: 1811-1847.

Panning A. (1944). Die Trepangfischerei. Mitteilungenausdem Zoologischen Staatsinstut und Zoologischen Museum Hamburg, 49: 1-76.

Pearson, J. (1903). Report on the Holothuroidea collected by Prof.Herdman, at Ceylon, in 1902. Report to the Government of Ceylon on the Pearl Oyster Fisheries of the Gulf of Manaar.Vol 1, Supplement 5, 181-208, pls 1-3.

Quay J.R.C and Gaimard J.P. (1833). Zoologoe: Zoophytes. In: Voyage de la corvette de 1 Astrolabeexcute par ordre due roi pendent les annees 1826- 1829 sous le commandement de M. J. Dumont d Urville : 1-390, pls 1-26.- Paris

Ramofafia, C., Foyle, T.P. and Bell, J.D. (1997). Growth of juvenile Actinopygamauritiana (Holothuroidea) in captivity. Aquaculture, 152:119-128. 
Rowe, F.W.E. (1969). A review of the family Holothuriidae (Holothurioidea: Aspidochirotida). Bulletin of the British Museum (Natural History) Zoology 18: 119-170.

Rowe F.W.E and Gates, J. (1995). Echinodermata, in A. Wells (ed.), Zoological Catalogue of Australia, vol. 33. (Melbourne: CSIRO Australia), pp. 510.

Samyn, Y. (2003). Shallow-water Holothuroidea (Echinodermata) from Kenya and Pemba Island (Tanzania).Studies in Afrotropical Zoology 292, 1-158.

Samyn Y., Appeltans, W and Kerr, A.M. (2005). Phylogeny of Labidodemasand the Holothuriidae (Holothuroidea: Aspidochirotida) as inferred from morphology. Zoolog. J. Linnean Society, 144: 103-120.

Selenka, E., (1867). Beitra" gezurAnatomie und Systematik der Holothurien. Zeitschriftfu“" rWissenschaftliche Zoologie, 17:291-374.

Stamatakis, A., Hoover, p.And Rougemont, J. (2008). A Rapid Bootstrap Algorithem for the RAxML web-server, Systematic Biology, 75(5): 758-771

Tan Tiu, A.S. (1981). The Intertidal Holothurian Fauna (Echinodermata: Holothuroidea) of Mactan and the Neigboring Islands, Central Philippines. Phillipine Scientist, 18: 45-119.

Uthicke, S., and J. A. H. Benzie. (2003). Gene flow and population history in high dispersal marine invertebrates: mitochondrial DNA analysis of Holothurianobilis (Echinodermata: Holothuroidea) populations from the Indo-Pacific. Mol. Ecol. 12: 2635-2648.

Yamanouchi, T. (1939). Ecological and physiological studies on the holothurians in the coral reef of Palao Islands.Palao Tropical Biological Station Studies, Report, 25: 603-634.

Zoutendyk, D. (1989). Trial processing and marketing of the surf redfish (Actinopygamauritiana) beche de-mer on Rarotonga, and its export potential in the Cook Islands. Ministry of Marine Resources Report., 13 p.

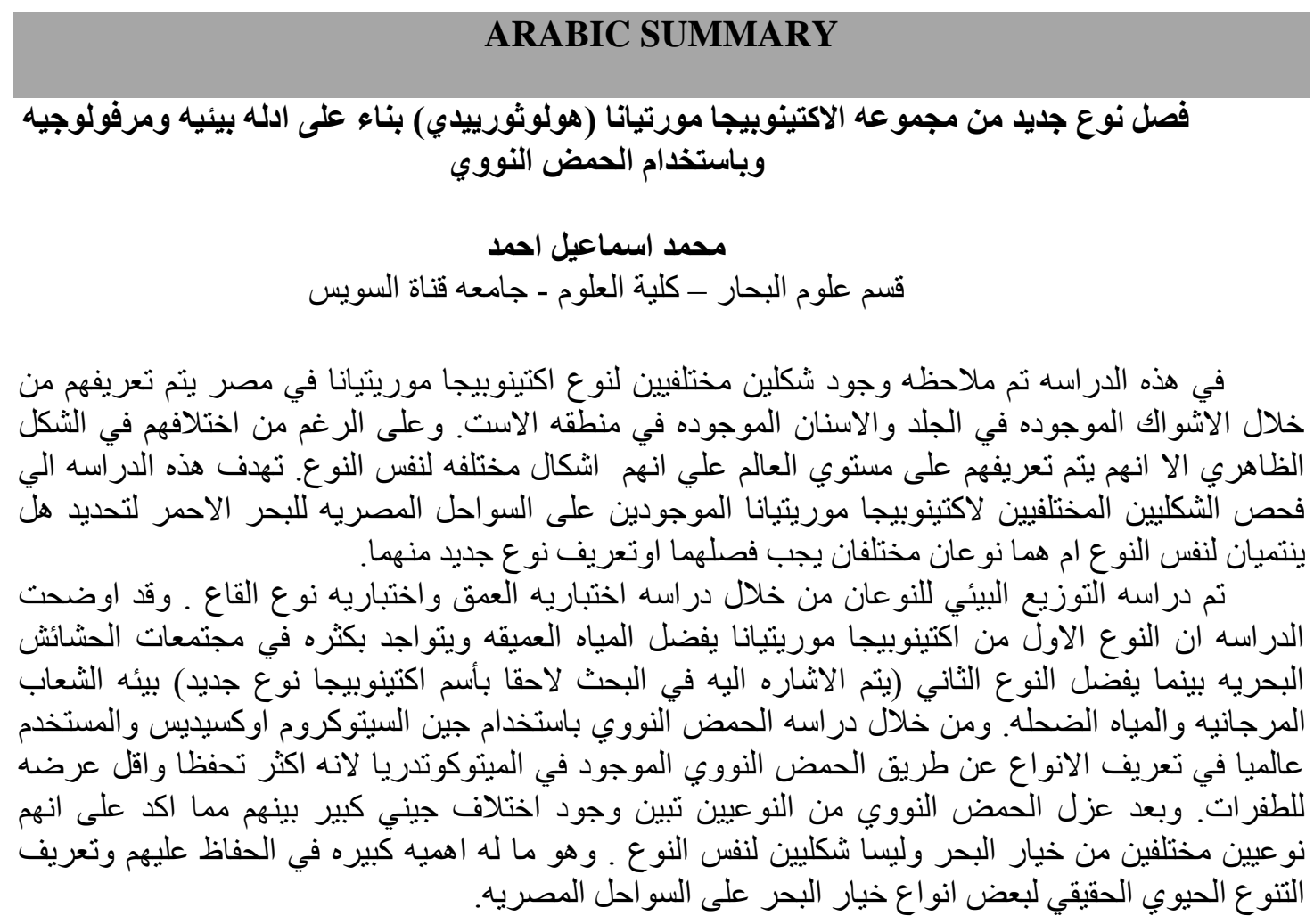

